\title{
NANOG Plays a Hierarchical Role in the Transcription Network Regulating the Pluripotency and Plasticity of Adipose Tissue-Derived Stem Cells
}

\author{
Maria Pitrone ${ }^{1}$, Giuseppe Pizzolanti ${ }^{1, *}$, Laura Tomasello ${ }^{1}$, Antonina Coppola ${ }^{1}$, Lorenzo Morini ${ }^{2}$, \\ Gianni Pantuso ${ }^{2}$, Romina Ficarella ${ }^{3}$, Valentina Guarnotta ${ }^{1}$, Sebastio Perrini ${ }^{3}$, Francesco Giorgino ${ }^{3}$ \\ and Carla Giordano ${ }^{1,4, *}$ \\ 1 Aldo Galluzzo Laboratory of Regenerative Medicine, Section of Endocrinology, Diabetology and Metabolism, \\ Di.Bi.M.I.S, University of Palermo, 90127 Palermo, Italy; maria.pitrone@unipa.it (M.P.); \\ laura.tomasello@unipa.it (L.T.); antonina.coppola02@unipa.it (A.C.); valentina.guarnotta@unipa.it (V.G.) \\ 2 Oncology Surgery, University of Palermo, 90127 Palermo, Italy; loremor86@yahoo.it (L.M.); \\ gianni.pantuso@unipa.it (G.P.) \\ 3 Endocrinology and Metabolic Diseases, University of Bari, 70124 Bari, Italy; r.ficarella@endo.uniba.it (R.F.); \\ sebastio.perrini@uniba.it (S.P.); francesco.giorgino@uniba.it (F.G.) \\ 4 ATeN (Advanced Technologies Network Center), University of Palermo, 90127 Palermo, Italy \\ * Correspondences: giuseppe.pizzolanti@unipa.it (G.P.); carla.giordano@unipa.it (C.G.); \\ Tel.: +39-091-6552138 (G.P.); +39-091-6552110 (C.G.); Fax: +39-091-6552138 (G.P.); +39-091-6552123 (C.G.)
}

Academic Editor: Gehua Zhen

Received: 18 January 2017; Accepted: 17 May 2017; Published: 23 May 2017

\begin{abstract}
The stromal vascular cell fraction (SVF) of visceral and subcutaneous adipose tissue (VAT and SAT) has increasingly come into focus in stem cell research, since these compartments represent a rich source of multipotent adipose-derived stem cells (ASCs). ASCs exhibit a self-renewal potential and differentiation capacity. Our aim was to study the different expression of the embryonic stem cell markers NANOG (homeobox protein NANOG), SOX2 (SRY (sex determining region Y)-box 2) and OCT4 (octamer-binding transcription factor 4) and to evaluate if there exists a hierarchal role in this network in ASCs derived from both SAT and VAT. ASCs were isolated from SAT and VAT biopsies of 72 consenting patients ( 23 men, 47 women; age $45 \pm 10$; BMI between $25 \pm 5$ and $30 \pm 5$ range) undergoing elective open-abdominal surgery. Sphere-forming capability was evaluated by plating cells in low adhesion plastic. Stem cell markers CD90, CD105, CD29, CD31, CD45 and CD146 were analyzed by flow cytometry, and the stem cell transcription factors NANOG, SOX2 and OCT4 were detected by immunoblotting and real-time PCR. NANOG, SOX2 and OCT4 interplay was explored by gene silencing. ASCs from VAT and SAT confirmed their mesenchymal stem cell (MSC) phenotype expressing the specific MSC markers CD90, CD105, NANOG, SOX2 and OCT4. NANOG silencing induced a significant OCT4 $(70 \pm 0.05 \%)$ and SOX2 $(75 \pm 0.03 \%)$ downregulation, whereas SOX2 silencing did not affect NANOG gene expression. Adipose tissue is an important source of MSC, and siRNA experiments endorse a hierarchical role of $N A N O G$ in the complex transcription network that regulates pluripotency.
\end{abstract}

Keywords: adipose derived stem cell (ASC); regenerative medicine; embryonic stem cell marker network

\section{Introduction}

Both visceral (VAT) and subcutaneous adipose tissues (SAT) represent an alternative source of mesenchymal stem cells (MSCs). Adipose-derived stem cells (ASCs) have been proposed by the International Fat Applied Technology Society as a plastic-adherent, proliferative, multipotent cell population isolated from adipose tissue [1,2]. ASCs have a fibroblastic-like morphology and possess 
the properties of MSCs traditionally isolated from bone marrow [3,4]. Furthermore, ASCs have a remarkable potential to differentiate in vitro towards the osteogenic, adipogenic, myogenic and chondrogenic lineages when maintained under specific culture conditions [5]. Nowadays, there is great interest in understanding more in detail the cellular and molecular mechanisms of ASCs, which are known to modulate self-renewal and differentiation properties. Indeed, the latter characteristics have made it possible to consider them as the preferable candidate for employment in regenerative medicine [6]. The role of the transcription factors that regulate self-renewal and differentiation is well known in embryonic stem cells [7]. Boyer et al. showed that OCT4 (octamer-binding transcription factor 4), NANOG (homeobox protein NANOG) and SOX2 (SRY (sex determining region Y)-box 2) work as a trio to support each other's expression and that of other self-renewal genes repressing differentiation genes [8], while other studies suggested that only OCT4 and NANOG are co-regulated in embryonic stem cells [7]. However, until today, the exact role of NANOG, OCT4 and SOX2 in adult stem cells isolated from different tissues has not been well identified and is still controversial $[9,10]$. For example, knockout of OCT4 did not affect their capacity for colony formation and differentiation into bone, fat and cartilage [11]. In addition, many studies showed the existence of pseudogenes for OCT4 [12] and NANOG that are not expressed in the nucleus, but in cytosol $[9,13]$, whose function has not so far been fully explained. Hyslop et al. suggested that NANOG acts as a gatekeeper of pluripotency in human embryonic development [14]. In this case, downregulation of NANOG in human embryonic stem cells (ESCs) induces upregulation of endoderm- and trophectoderm-associated genes [13-15]. As regards hASCs, the single components of the trio have been described separately, but the possible interplay among the principal transcription factors has not been fully explored.

Our aim was to study the expression of NANOG, SOX2 and OCT3/4 in ASCs derived from SAT and VAT and to evaluate whether there exists a transcription factor with a more prominent role in this network.

\section{Results}

\subsection{Isolation of Adipose Derived Stem Cells}

Enzymatic digestion of biopsied human adipose tissue was obtained from 72 consenting patients (23 men and 47 women; age $45 \pm 10$ years; with body mass index (BMI) range $25 \pm 0.5$ and $35 \pm 5$, respectively) undergoing elective open-abdominal surgery. The freshly-isolated stromal vascular cell fraction (SVF) was a compounded cell population with a spindle, triangular, polygonal or round shape, which contained fibroblasts and adipocytes at different differentiation stages. These cells adhered to a flask without a substrate. After $48 \mathrm{~h}$, observation under a light microscope showed a round and small morphology (Figure 1A), whilst after five days (Figure 1B), these cells extended and showed a spindle shape. After seven days, the number of some mature cells, such as mature adipocytes, decreased, and the morphology of most cells tended to be uniform. After 10 days (Figure 1C), colonies of fibroblastic-like cells were observed, although fibroblasts mixed in ASCs were still found. Both of these cell types reached confluence after about 15 days. MSCs derived from visceral adipose tissue (V-ASCs) were characterized by large nuclei and elongated cytoplasms (Figure 1D) and those derived from subcutaneous adipose tissue (S-ASCs) by large nuclei and globular cytoplasms (Figure 1E). Both S-ASCs and V-ASCs formed cell aggregation at the third passage (Figure 1F,G) and in low-adhesion culture conditions formed spheres, suggesting the stem origin of the cells (Figure 1H,I). 

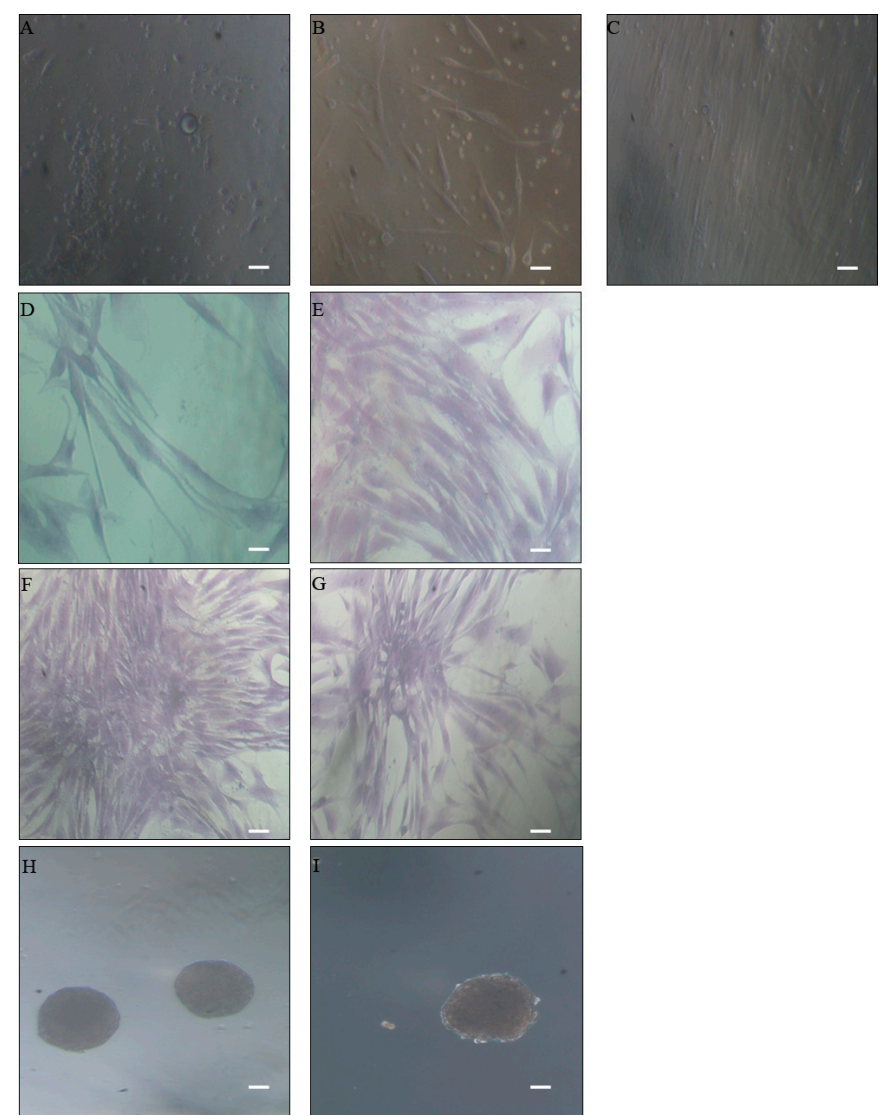

Figure 1. Morphology of adipose-derived stem cells (ASCs) under light microscopy (10×) with phase contrast with a Nikon DS-FI1 CCD camera. Scale bars: $400 \mu \mathrm{m}$. Stromal vascular cell fraction (SVF) morphological characteristics on day 2 (A), day 5 (B) and day 10 (C) of expansion cultures. Crystal violet staining shows visceral adipose tissue mesenchymal stem cells (V-ASCs) having large nuclei and extended cytoplasms (D) in comparison to subcutaneous adipose tissue mesenchymal stem cells (S-ASCs), which have large nuclei and globular cytoplasms (E); (F,G) show similar aggregation of MSCs from V-ASC and S-ASC in adhesion cultures; (H,I) show spheres from V-ASCs and S-ASCs in low adhesion cultures. An experiment representative of 72 samples studied is shown.

\subsection{Cell Cycle Analysis}

Cell cycle analysis at passage 3 showed no significant different distribution of cells in the G1, G2 and S phases in S-ASC and V-ASC. S-ASC in the G1 phase was $68.10 \pm 2.32 \%$ and V-ASC was $66.01 \pm 3.43 \%$. The proliferation index (PI), expressed as \% G2 + \% M, was $10.3 \pm 3.7 \%$ and $9.46 \pm 2.14 \%$, respectively, for S-ASC and V-ASC (Figure 2).

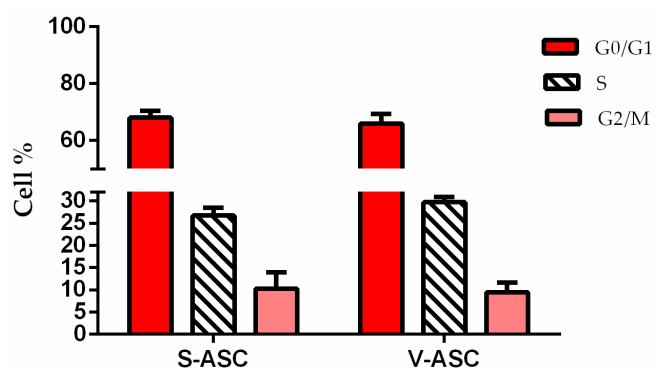

Figure 2. Cell cycle distribution of S-ASCs and V-ASCs. Both cell types were analyzed according to Nicoletti's protocol [16]. Twenty-five samples of S-ASCs and V-ASCs cultured in adhesion condition at passage 3 were analyzed. 


\subsection{Flow Cytometry Stem Cell Phenotype Characterization}

The cell-surface antigenic characteristics of 12 samples of S-ASCs and 12 samples of V-ASCs at passage 3 were analyzed by flow cytometry. Both populations were positive for CD90 (94 $\pm 3.9 \%$ and $91 \pm 3.6 \%$, respectively), CD105 (76 $\pm 4.2 \%$ and $73 \pm 2.7 \%$, respectively) and CD29 (72 $\pm 2.5 \%$ and $70.8 \pm 2.8 \%$, respectively) (Figure 3A) and showed almost no expression of CD31, CD45 and CD146 $(<1 \%)$ (Figure 3B).
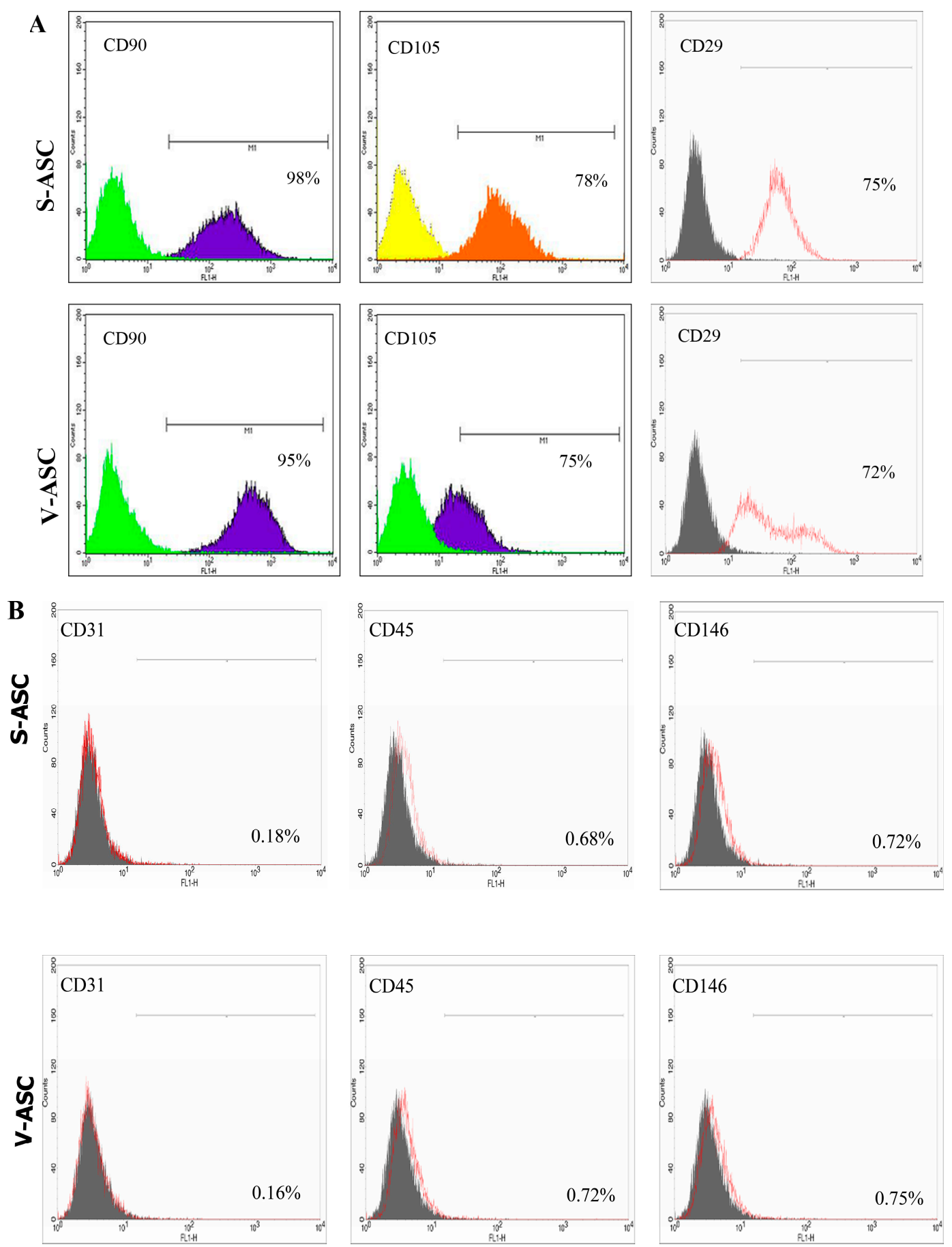

Figure 3. (A) Cytofluorimetric analysis for CD90, CD105 and CD29; (B) The cells are negative for CD31, CD45 and CD146 in S-ASC and V-ASC. All fields are representative of one S-ASC and V-ASC sample out of at least 12 independent experiments. 


\subsection{Stem Cell Markers of S-ASC and V-ASC Grown as Adherent Cells or Spheres}

To assess the multipotent state of ASCs from subcutaneous and visceral adipose tissue, we detected some of the embryonic stem cell markers, such as ABCG2, OCT4, SOX2, C-KIT, THY1, CD-73, CD-105 and NANOG, using mRNA samples from 10 S-ASCs and 10 V-ASCs cultured in adhesion conditions. Expression analysis (see Table S1 in supplementary) showed only a significant difference in NANOG mRNA levels in S-ASC vs. V-ASC. ASCs from VAT and SAT expressed all of the examined stem cell markers (Figure 4A).

Furthermore, we compared the stem cell transcription factor expression pattern in spheres derived from S-ASCs and V-ASCs vs. S-ASCs and V-ASCs in adhesion condition cultures. We found that NANOG, SOX2 and OCT4 were expressed at higher levels in spheres from S-ASC and V-ASC cells in comparison to the same cells in adhesion conditions (see Table S2 in supplementary). In addition, spheres from S-ASCs were characterized by the highest values, as shown in Figure $4 \mathrm{~B}(p<0.01)$.
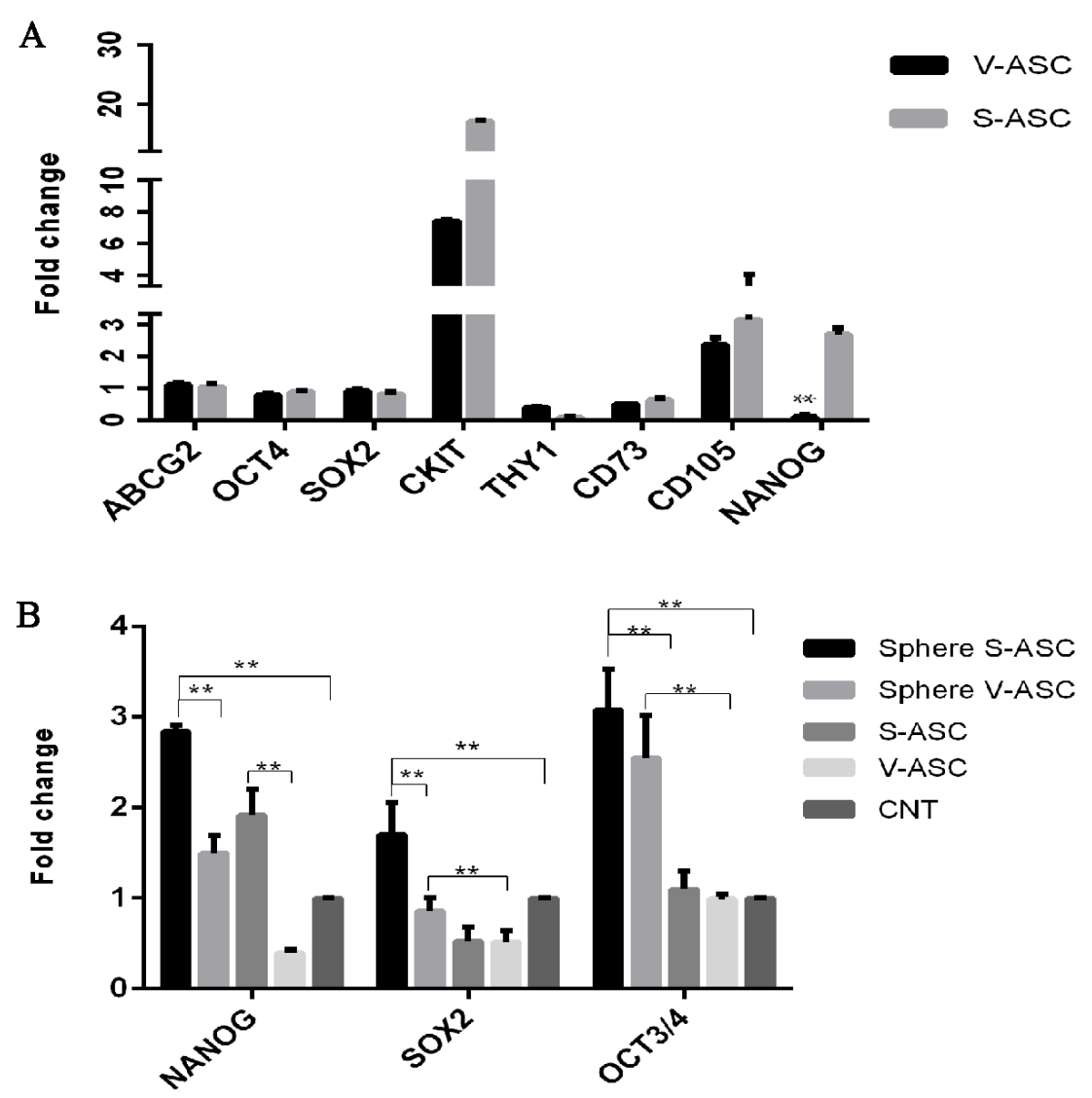

Figure 4. (A) qRT-PCR analyses in S-ASC and V-ASC cells cultured in adhesion condition. Data are representative of three independent experiments. Relative expression levels for ABCG2, OCT4, SOX2, CKIT, THY1, CD73, CD105 and NANOG were assessed using the $2^{-\Delta \Delta C t}$ method. Values shown as mean $\pm \mathrm{SE},{ }^{* *} p<0.01$. The data shown are relative to an endogenous control (beta-actin), with the fold change compared to expression levels in commercial bone marrow-mesenchymal stem cells (set to one); (B) qRT-PCR analysis in spheres from S-ASC and V-ASC primary cells. Data are representative of three independent experiments with the fold change compared to expression levels in commercial human adipose derived stem cell (ASC52telo, hTERT immortalized adipose-derived mesenchymal stem cells) (set to one). Values shown as the mean $\pm \mathrm{SE},{ }^{* *} p<0.01$. CNT, control.

Western blot analysis confirmed that NANOG was more expressed in ASCs isolated from SAT than from VAT $(p<0.01)$ (see Table S3 in supplementary) (Figure 5A,B). 

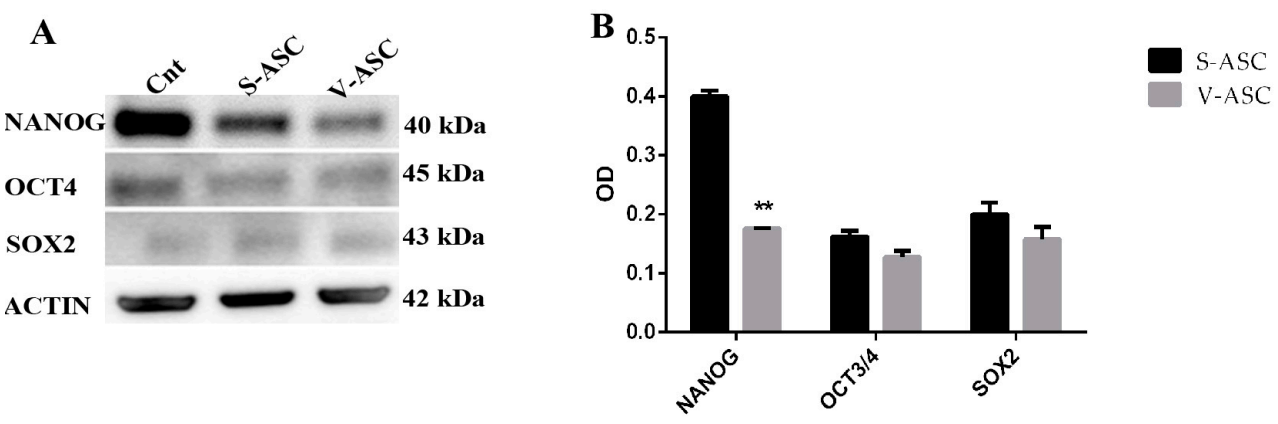

Figure 5. (A) Representative Western blot analysis in the S-ASC and V-ASC cells of NANOG, OCT3/4 and SOX2; (B) densitometric analysis of the Western blot depicted in (A). The histograms are the results of three independent experiments. The values are shown as the mean $\pm \mathrm{SE},{ }^{* *} p<0.01$. OD, optical density $\left.{ }^{* *} p<0.01\right)$.

\subsection{NANOG and SOX2 Silencing in S-ASC and $V-A S C$}

To establish the relationship between $S O X 2, O C T-4, N A N O G$, we evaluated their expression after NANOG silencing. NANOG silencing (Figure 6A,B) in S-ASCs after $48 \mathrm{~h}(73 \pm 0.03 \%)$ and after $72 \mathrm{~h}$ $(70 \pm 1.23 \%)$ and in V-ASCs cultured in adhesion after $48(70 \pm 1.4 \%) \mathrm{h}$ and $72 \mathrm{~h}(72 \pm 2.3 \%)$ caused downregulation of OCT3/4 $(70 \pm 0.05 \%, p<0.01)$ and SOX2 genes $(75 \pm 0.03 \%, p<0.01)$ in S-ASCs (Figure 7A,B) and in V-ASCs (Figure 7C,D).

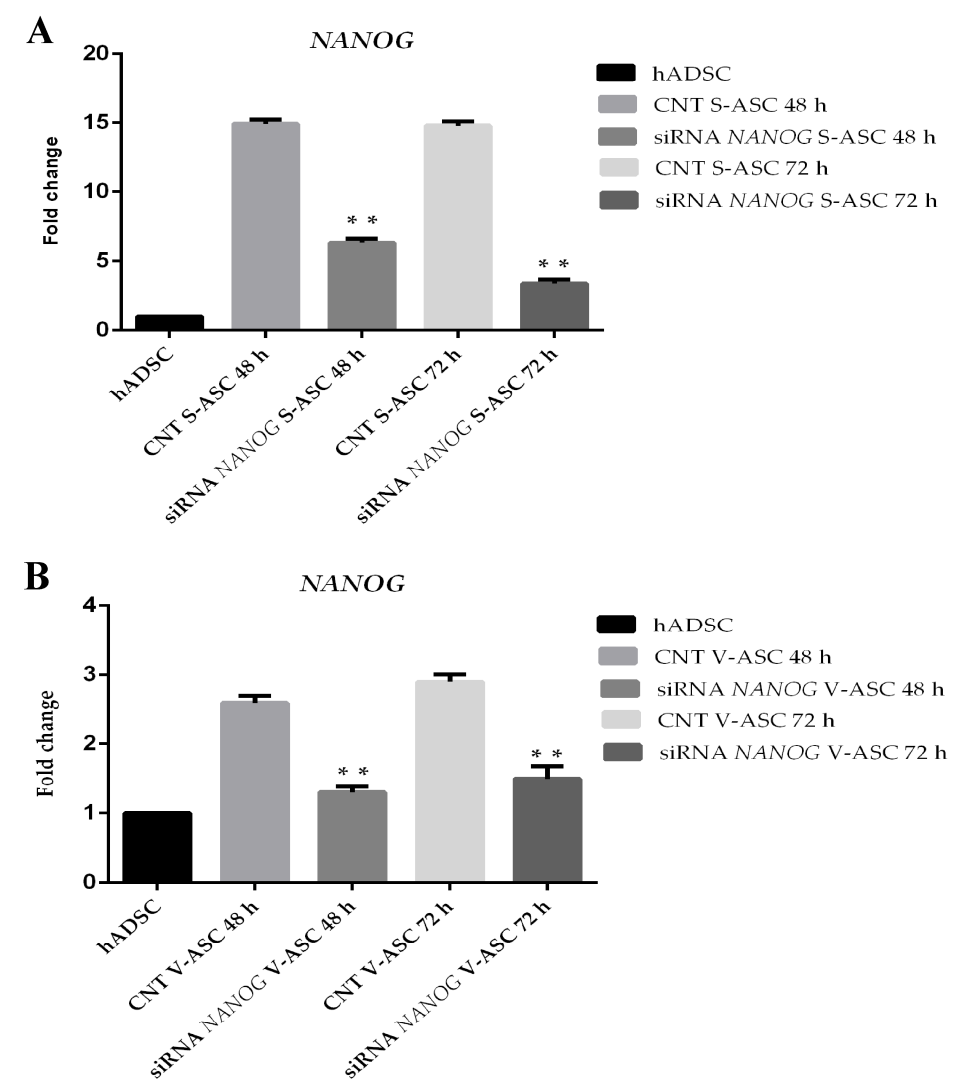

Figure 6. (A) NANOG silencing in S-ASCs after 48 and $72 \mathrm{~h}$; (B) NANOG silencing in V-ASCs after 48 and $72 \mathrm{~h}$. Fold change was calculated using the $2^{-\Delta \Delta \mathrm{Ct}}$ method. Data representative of three independent experiments with the fold change compared to expression levels in a commercial human adipose-derived stem cell line (ASC52telo, hTERT immortalized adipose-derived mesenchymal stem cells). Values shown as the mean $\pm \mathrm{SE},{ }^{* *} p<0.01$. 
A
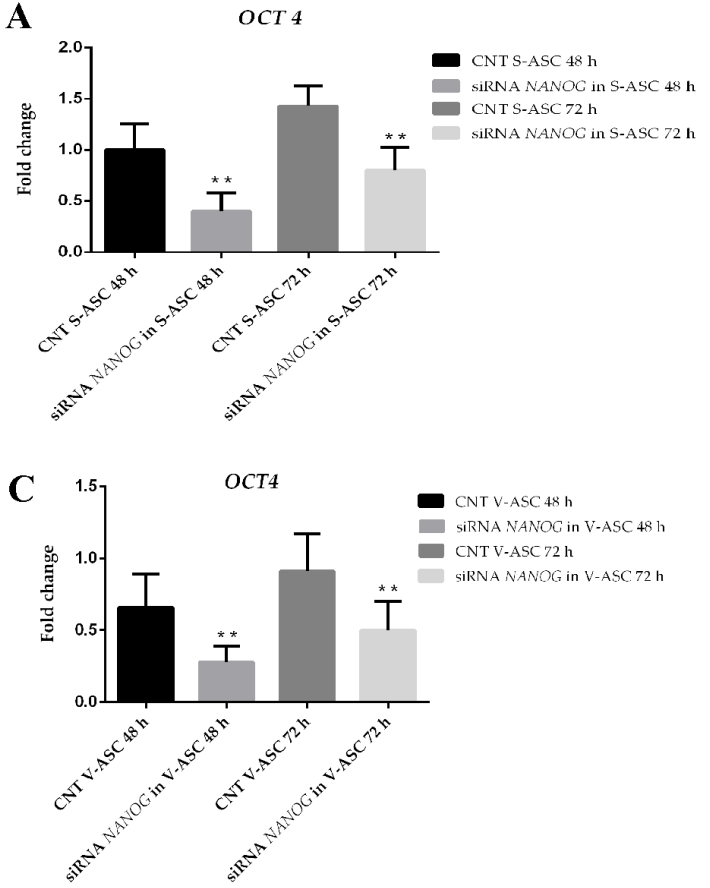
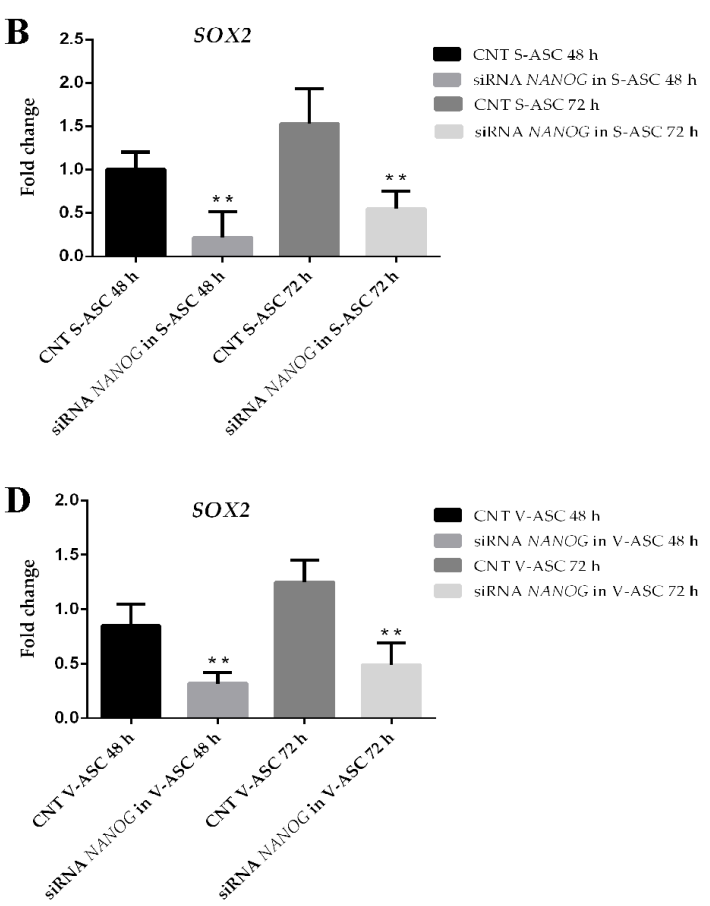

Figure 7. (A) qRT-PCR analysis in S-ASCs of the OCT4 gene after NANOG silencing; (B) qRT-PCR analysis in S-ASCs of the SOX2 gene after NANOG silencing; (C) qRT-PCR analysis in V-ASCs of the OCT4 gene after NANOG silencing; (D) qRT-PCR analysis in V-ASCs of the SOX2 gene after NANOG silencing. NANOG silencing was assessed with stealth siRNA (siRNANANOG) vs. siCONTROL treated cells $(\mathrm{CNT})$. The data are representative of three independent experiments. The values are shown as the mean $\pm \mathrm{SE},{ }^{* *} p<0.01$.

By contrast, SOX2 silencing after $48 \mathrm{~h}(72 \pm 1.5 \%)$ and $72 \mathrm{~h}(70 \pm 2.3 \%)$ (Figure $8 \mathrm{~A})$ in S-ASCs cultured in adhesion showed no effect on NANOG and OCT4 expression after $48 \mathrm{~h}$ (Figure 8B,C).

A

A
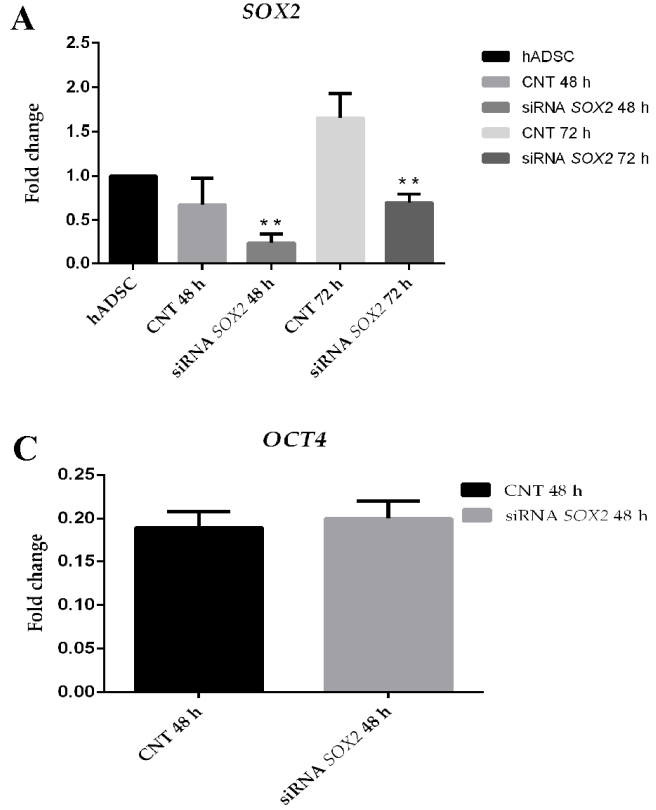

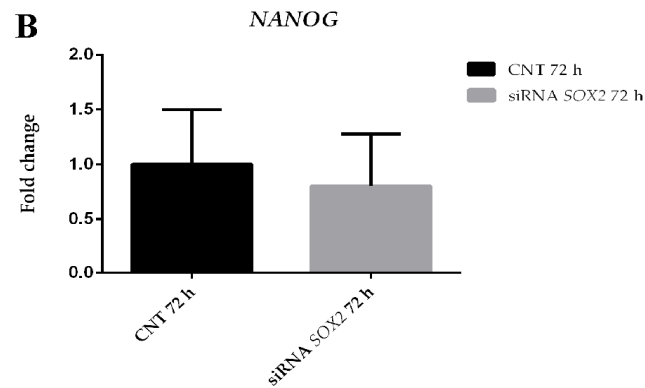

Figure 8. (A) SOX2 silencing assessed using the $2^{-\triangle \Delta C t}$ method; (B) qRT-PCR analysis in S-ASCs of NANOG and OCT4; (C) gene expression after SOX2 silencing with stealth siRNA (siRNASOX2) vs. siCONTROL treated cells (CNT). The data are representative of three independent experiments. 
Western blot analysis of SOX2 and OCT3/4 after NANOG silencing with stealth siRNA after $96 \mathrm{~h}$ in S-ASCs (optical density $(\mathrm{OD})=0.8 \pm 0.1$ and $0.24 \pm 0.01, p<0.01$ ) and in V-ASCs (OD $=0.5 \pm 0.01$ and $0.22 \pm 0.01)$ caused downregulation of the OCT4 protein in S-ASCs $(\mathrm{OD}=1.16 \pm 0.17$ vs $0.38 \pm 0.12 ; p<0.01$ ) and in V-ASCs (OD =1.09 \pm 0.16 vs. $0.39 \pm 0.12, p<0.01)$. At the same time, downregulation of the SOX2 protein was observed in S-ASCs (OD: $0.49 \pm 0.05$ vs. $0.20 \pm 0.02$; $p<0.01$ ) and in V-ASCs (OD: $0.5 \pm 0.01$ vs. $0.01 \pm 0.001 ; p<0.01$ ) (Figure 9).

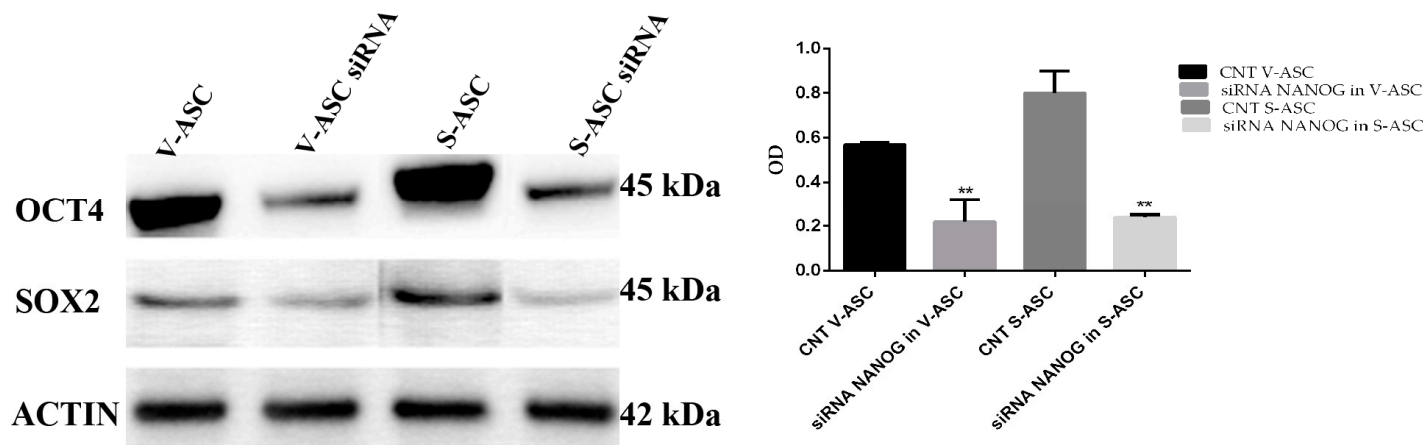

Figure 9. Western blot of OCT4 and SOX2 with proteins extracted from V-ASC and S-ASC cells after NANOG silencing with stealth siRNA vs. siCONTROL treated cells.

By contrast, SOX2 silencing in S-ASC (OD = $1.3 \pm 0.1$ vs. $0.23 \pm 0.06, p<0.01)$ and in V-ASC cells $(\mathrm{OD}=1.16 \pm 0.013$ vs. $0.56 \pm 0.04 ; p<0.01)$ (Figure $10 \mathrm{~A})$ after $96 \mathrm{~h}$ was not able to affect NANOG protein levels in S-ASC (OD = $1.17 \pm 0.1$ vs. $1.2 \pm 0.01, p=\mathrm{NS})$ and in $\mathrm{V}-\mathrm{ASC}(\mathrm{OD}=0.7 \pm 0.2 \mathrm{vs}$. $0.68 \pm 0.1 ; p=\mathrm{NS}$ ) (Figure 10B).

A

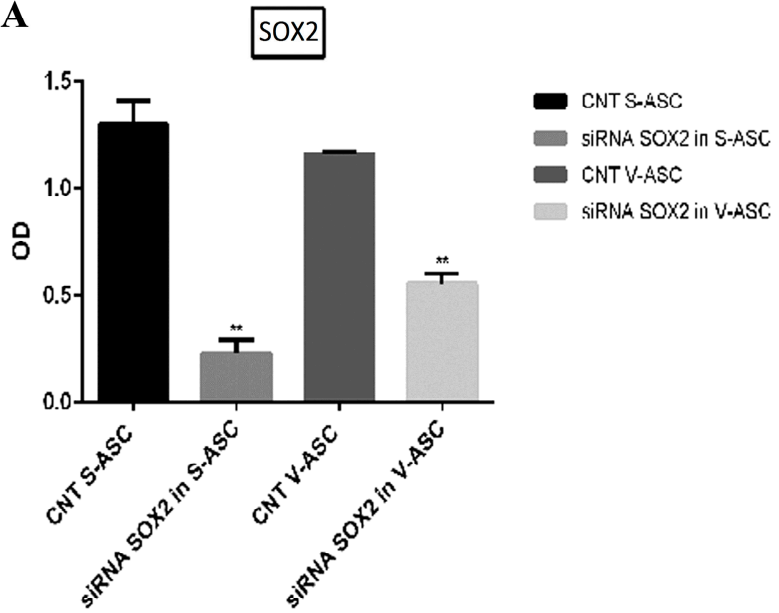

B

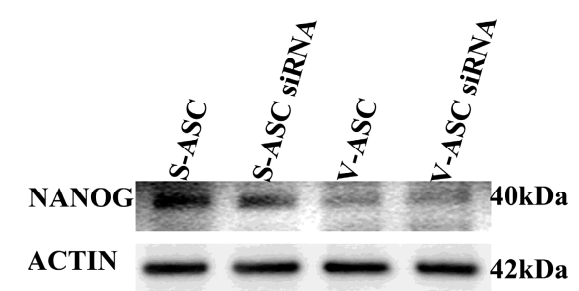

Figure 10. (A) Analysis of SOX2 silencing after 96 h; (B) Western blot of NANOG with proteins extracted from S-ASC and V-ASC cells after SOX2 silencing with stealth siRNA vs. siCONTROL (CNT) treated cells. The results were normalized with beta actin. The data are representative of three independent experiments.

\section{Discussion}

Adipose tissue represents an interesting source of multipotent stem cells [5,16] and is considered fundamental for comprehension of adipose tissue biology under normal physiology. In addition, interest in disease state conditions is also developing, even though limited information is available on visceral and subcutaneous ASCs and the relationship between in vitro and in vivo adipogenesis. 
The purpose of this work was to study the different expression of the embryonic stem cell markers NANOG, SOX2 and OCT3/4 and the role of NANOG in this network, evaluated in both S-ASCs and V-ASCs isolated from SAT and VAT in a large series of obese and non-obese subjects, who underwent elective open-abdominal and laparoscopy surgery. When isolated MSCs were cultured without any substrate [17], we observed morphological differences in V-ASC and S-ASC cells, which included cell shape and cell size in accordance with previous observations [18,19]. ASCs derived from subcutaneous adipose tissue were characterized by large nuclei and cytoplasms and formed cell aggregation (fusiform shape), whilst ASCs derived from visceral adipose tissue showed large nuclei and extended cytoplasms (classical fibroblast-like). Our data confirm that cells are capable of forming sphere clusters in a serum-free medium supplemented with fibroblast growth factor-basic (FGF-b) and epidermal growth factor (EGF) [20], and these spheres derived from S-ASCs and V-ASCs expressed all of the ESC markers evaluated, SOX-2, OCT4 and NANOG, more markedly than S-ASCs and V-ASCs in adhesion, demonstrating that the spheres mostly possess stemness potential. Interestingly, during the time of floating culture, the spheres maintained the expression of stem cell markers. From our findings, it is possible to confirm that cultures in low adhesion conditions can be used to maintain stem characteristics for a longer time than traditional adhesion cultures. Immunophenotyping of MSCs derived from subcutaneous and visceral adipose tissue demonstrate that cell populations express well-defined MSC-associated surface markers CD29, CD73, CD90 and CD105 [20,21]. Western blot analysis confirmed the presence of stem cell markers; both ASCs were positive for SOX2, OCT3/4 and NANOG, which are the principal transcription factors that regulate pluripotency and plasticity. Our results indicate that the stemness of ASCs should be defined by their ability to differentiate into multiple lineages coupled with their expression of the pluripotent stem cell-related genes OCT-4, SOX2 and NANOG. This datum could be considered useful to functionally distinguish ASCs as more stem cell-like [22]. We found that the embryonic stem cell marker NANOG is also over-expressed in MSCs derived from adipose tissue, confirming recent studies that have demonstrated a central role of NANOG in embryonic stem cells [23].

Stem cell pluripotency and differentiation are strictly controlled by a coordinated network of transcription factors [24]. Among them, OCT4 and NANOG have been recognized as crucial transcriptional regulators of stem cell self-renewal during embryogenesis $[25,26]$. More recently, it has been shown that both OCT4 and NANOG are also expressed by undifferentiated adult MSCs [27-29]. In ESCs, the over-expression of NANOG, the homeobox-containing transcription factor, is considered fundamental in maintaining the pluripotency and self-renewing characteristics of culture conditions inducing under-differentiation [24]. Recent studies have identified the downstream targets of OCT4, which include genes encoding for self-renewal factors, lineage-specific factors, signaling molecules and DNA damage response sensors [25]. Thus, OCT4 is involved in a broad spectrum of cellular processes that collectively specify the self-renewal state of the ESCs. On the other side, the role of SOX2 seems to be crucial, as well. Indeed, the lack of SOX2 leads ESCs to differentiation and to the loss of pluripotency property [30]. Based on these data, NANOG is considered a core element of the pluripotent transcriptional network. Transient downregulation of NANOG appears to predispose cells towards differentiation, but does not mark commitment. Therefore, unlike OCT4 and SOX2, NANOG plays a pivotal role in the maintenance of the epiblast and ES cells by repressing differentiation along the primitive endoderm lineage. SOX2 is capable of hetero-dimerizing with OCT4 to mediate the transcription activities of several ES cell-specific genes including NANOG [31]. Interestingly, OCT4 and SOX2 are also involved in reciprocal regulation of each other's expression [32]. OCT4 overexpression induces de-differentiation of ASCs into a more immature status by activating the AKT/phosphoinositide 3-kinase (PI3K) and extracellular signal-related kinase (ERK1/2) signaling pathways [33]. Indeed, it has been reported that ASCs possess their own multipotency to reprogram into more primitive stem cells [34]. However, how this process takes place mechanistically remains controversial. Suzuki et al showed that NANOG expression is not regulated by Brachyury $T$ and STAT3 in mouse ESCs [35]. In human ESCs, Vallier et al. showed that activin/nodal signaling stimulates 
the expression of $N A N O G$, which in turn prevents FGF-induced neuroectoderm differentiation [36]. In addition, several studies have demonstrated that the OCT4/SOX2 complex is directly bound to the NANOG promoter for the target gene regulation [37]. Today, OCT4, SOX2 and NANOG are known to bind the same regulatory regions in undifferentiated mouse and human ESCs, and these binding sites are often in close proximity to one another [38]. These studies suggest that OCT4, SOX2 and NANOG can physically interact with each other and coordinately regulate target genes [37,39].

In our experiments, we observed that downregulation of NANOG leads to significant downregulation of OCT4 and SOX2, probably consistent with the loss of pluripotency. Indeed, in previous studies, downregulation of NANOG was shown to lead to significant downregulation of OCT4 and loss of ES/EC cell-surface antigens; upregulation of several marker genes, including GATA4, GATA6, LAMININ B1 and AFP $[30,40,41]$ was reported. Moreover, the trophectoderm specification is indicated by upregulation of $C D X 2$, GATA2, $h C G-\alpha$ and $h C G-\beta[23,28,39,42,43]$.

All of these data confirm the use of adipose tissue as a potential source for multipotent cells and above all propose a suitable approach for future regenerative medicine and tissue engineering applications, as well as overall confirm its being a valuable resource in biotechnology.

\section{Materials and Methods}

\subsection{Establishment of Adipose-Derived Stem Cell Cultures}

Subcutaneous (SAT) and visceral (VAT) adipose tissue biopsies were obtained from 72 consenting patients ( 23 men, 47 women; age $45 \pm 10$; BMI range between $25 \pm 0.5$ and $35 \pm 5$ ), 42 obese and 28 non-obese subjects undergoing elective open-abdominal and laparoscopy surgery. The protocol was approved for RIMEDRI by the Independent Ethical Committee at the Azienda Ospedali Riuniti Villa Sofia-Cervello, No. 15, 11 December 2013, Palermo, Italy. All patients gave their written informed consent. Adipose tissue specimens were obtained from the subcutaneous and omental depots, and approximately $1 \mathrm{~g}$ of adipose tissue was taken from each fat depot. All biopsies were handled under sterile conditions and immediately used for subsequent preadipocyte isolation. Tissue specimens were immediately transported to the clean room of the laboratory of Regenerative Medicine (ISO 14644 Ec-GMP) in DMEM/Ham's F12 1:1, dissected from fibrous material and visible blood vessels, cut into little fragments and incubated in PBS Ca ${ }^{2++} / \mathrm{Mg}^{++}$(Phosphate-Buffered Saline with Calcium and Mangnesium) (Sigma Chemical, St. Louis, MO, USA) supplemented with $1 \mathrm{mg} / \mathrm{mL}$ collagenase type I (Sigma Chemical, St. Louis, MO, USA), with vigorous shaking (100 cycles/min) for $1 \mathrm{~h}$ at $37^{\circ} \mathrm{C}$. The resulting material was filtered through a $250-\mathrm{mm}$ mesh, and adipocytes and free oil were separated from stromal vascular (SVF) components by centrifugation at $1200 \mathrm{rpm}$ for $5 \mathrm{~min}$ at room temperature. The SVF pellet was resuspended in a growth medium consisting of DMEM/Ham's F12 1:1 supplemented with 100 units $/ \mathrm{mL}$ penicillin, $0.1 \mathrm{mg} / \mathrm{mL}$ streptomycin, $5 \%$ fetal calf serum (FCS), $1 \mathrm{ng} / \mathrm{mL}$ FGF-b and $10 \mathrm{ng} / \mathrm{mL}$ EGF.

\subsection{Sphere Cultures}

SVF cells were seeded at $1 \times 10^{2}$ cell $/ \mathrm{cm}^{2}$ in ultra-low adherent flasks (Corning, Avon, France) in defined culture medium, which consisted of DMEM/F12 supplemented with L-glutamine (2 mM), nonessential amino acids $(1 \times)$, B27 $(1 \times)$ (Invitrogen, Milan, Italy), human FGF-b $(20 \mathrm{ng} / \mathrm{mL})$, human EGF $(20 \mathrm{ng} / \mathrm{mL})$. Cells were incubated at $37^{\circ} \mathrm{C}$ under $5 \% \mathrm{CO}_{2}$, and half of the medium was changed once a week. Sphere formation was assessed by counting the number of spheres (cells $>3$ ) under an optical microscope. To test if sphere-containing cells can revert to monolayer growth, spheres were dissociated with accutase (Sigma Chemical) and plated in flasks treated for cell culture (TPP) in ASC expansion medium. 


\subsection{Evaluation of Morphological Characteristics}

Cells were fixed for $15 \mathrm{~min}$ at RT in $2 \%(w / v)$ paraformaldehyde, washed twice in distilled water and stained with crystal violet. Then, the cells were observed for their morphological features under a Zeiss phase contrast microscope (Zeiss, Gottingen, Germany) and photographed with a Nikon camera (Nikon, Firenze, Italy).

\subsection{Flow Cytometry Analysis}

Cells isolated from 12 samples of S-ASC and 12 samples of V-ASC were harvested and filtered through a $40-\mu \mathrm{m}$ filter mesh and suspended at the concentration of $1 \times 10^{6}$ cells $/ \mathrm{mL}$. Then, $100 \mu \mathrm{L}$ of cell suspension containing $5 \times 10^{5}$ cells were used for each flow cytometric test.

\subsection{Immunophenotyping}

Human anti-CD31, human anti-CD45, human anti-CD146, human anti-CD29, human anti-CD90 and human anti-CD105 (see Table 1) monoclonal antibodies were tested on S-ASC and V-ASC. The incubation conditions were in accordance with the manufacturer's instructions. For anti-CD90 and anti-CD105, cells were washed twice with PBS/bovine serum albumin (BSA) $5 \%$ and incubated with Alexa Fluor 488 goat anti-mouse IgG (Invitrogen, Carlsbad, CA, USA) antibody for $1 \mathrm{~h}$ in the dark. Data were acquired on a FACS Calibur and analyzed using CELL Quest Pro software (Becton Dickinson, Franklin Lakes, NJ, USA).

Table 1. Monoclonal antibodies used for the characterization of cell phenotypes.

\begin{tabular}{cccc}
\hline Primary Antibody/Localization Marker & Code Number & Diluition & Incubation \\
\hline CD31, surface & Miltenyi Biotec, 130-092-654 & $1: 100$ & $30 \mathrm{~min}$, r.t. \\
CD45, surface & Miltenyi Biotec, 130-080-202 & $1: 100$ & $30 \mathrm{~min}$ r.t. \\
CD146, surface & Miltenyi Biotec, 130-092-851 & $1: 100$ & $30 \mathrm{~min}$, r.t. \\
CD90, surface & Chemicon, CBL415 & $1: 50$ & o/n, r.t. \\
CD105, surface & Biolegend,323202 & $1: 50$ & o/n, r.t. \\
CD29, surface & Miltenyi Biotec, 130-101-256 & $1: 100$ & 30 min, r.t. \\
Secondary antibody & Code Number & Diluition & Incubation \\
AlexaFluor 488 & Life Technologies, Z25402 & $1: 50$ & 20 min, r.t. \\
\hline
\end{tabular}

Miltenyi Biotec, Bergisch Gladbach, Germany; Santa Cruz, Dallas, Texas; BioLegend, London, UK; Life Technologies, Carlsbad, CA, USA; o/n, overnight; r.t., room temperature.

\subsection{Analysis of Cell Cycle Status of MSCs}

Single-cell suspensions of 25 samples of S-ASC and 25 samples of V-ASC were obtained and seeded at a density of $2 \times 10^{3}$ cells $/ \mathrm{cm}^{2}$ (passage 3), and the DNA content was assessed according to Nicoletti's protocol. Briefly, $1 \times 10^{6}$ cells were fixed in $70 \%$ ethanol, rehydrated in PBS and then re-suspended in a DNA extraction buffer (with $0.2 \mathrm{M} \mathrm{NaHPO}_{4}, 0.1 \%$ Tritonx-100 and, pH 7.8). Cells were stained with $1 \mu \mathrm{g} / \mathrm{mL}$ of propidium iodide (PI) for $5 \mathrm{~min}$; fluorescence intensity was determined by analysis on a FACS Calibur (Becton Dickinson). Data were acquired with CellQuest Pro software (Becton Dickinson) software, and the percentages of G1, S and G2 phase cells were calculated with the MODFIT-LT 5.0 software program (Verity Software House Inc., Topsham, ME, USA).

\subsection{RNA Isolation and Quantitative RT-PCR}

mRNA from ASCs populations isolated from VAT and SAT biopsies derived from obese and normal weight patients were isolated using an RNeasy kit (Qiagen, Hamburg, Germany). Two hundred fifty nanograms of RNA from S-ASC and V-ASC were reverse-transcribed with standard reagents (Promega, Madison, WI, USA). One microliter of each reverse-transcription reaction was amplified using SYBR Green PCR master mix from Qiagen (Quantitect SYBR green master mix), using the RotorGene PCR system (Qiagen, Hamburg, Germany). For each gene, mRNA expression was 
normalized for the housekeeping gene $\beta$-actin. Amplification of specific transcripts was confirmed by melting curve profiles at the end of each PCR. PCR primers, OCT4, NANOG, THY-1 (CD-90), CD105 and $C D 73$ were purchased from Qiagen (QuantiTect ${ }^{\circledR}$ Primer Assays, Qiagen); primer for SOX2 was purchased from MWG (Eurofins Genomics, Ebersberg, Germany); and primer for $\beta$-actin was purchased from Invitrogen (Table 2) All reactions were performed using the Quantitect SYBR Green PCR Kit (Qiagen) on the RotorGene Q Instrument (Qiagen). Each cDNA sample was mixed with specific primer sets and PCR master mix. The PCR reactions were performed using the following parameters for 40 cycles: denaturation at $95^{\circ} \mathrm{C}$ for $3 \mathrm{~min}, 95^{\circ} \mathrm{C}$ for $20 \mathrm{~s}$, annealing at $60^{\circ} \mathrm{C}$ for $30 \mathrm{~s}$ and elongation at $72{ }^{\circ} \mathrm{C}$ for $60 \mathrm{~s}$. Reactions were performed at least in triplicate. The specificity of the amplified products was determined by melting peak analysis. The relative quantification model with efficiency correction was applied to normalize the expression of the target gene to $\beta$-actin (used as a housekeeping gene) and to compare gene expression with bone marrow mesenchymal stem cell(BM-MSCs) and with a commercial primary cell line immortalized with a human telomerase reverse transcriptase (hTERT) immortalized cell lines (ASC52telo, hTERT immortalized adipose-derived mesenchymal stem cells (ATCC ${ }^{\circledR}$ SCRC-4000 ${ }^{\mathrm{TM}}$, American Type Culture Collection, Manassas, VA, USA), used as a positive cell control. Relative expression levels for ABCG2, OCT4, SOX2, CKIT, THY1, $C D 73, C D 105$ and NANOG were assessed using the $2^{-\Delta \Delta C t}$ method. The results were represented as histograms with GraphPad Prism 6 Software (GraphPad Software, Inc. La Jolla, CA, USA). The qRT-PCR analyses for the stem gene were also performed after siRNA transfection experiments.

Table 2. Real-time quantitative PCR primers used for gene expression investigation.

\begin{tabular}{|c|c|c|}
\hline RNA & Primer Sequence & Code Number \\
\hline$A B C G 2$ & Qiagen ${ }^{\circledR}$ & QT00073206 \\
\hline NANOG & Qiagen ${ }^{\circledR}$ & QT01844808 \\
\hline OCT3/4 & Qiagen ${ }^{\circledR}$ & QT00210840 \\
\hline SOX2 & $\begin{array}{l}\text { FORWARD: } 5^{\prime} \text {-GGAGACGGAGCTGAAGCCGC-3' } \\
\text { REVERSE: 5'-GACGCGGTCCGGGCTGTTTT-3' }\end{array}$ & \\
\hline THY1 & Qiagen ${ }^{\circledR}$ & QT00023569 \\
\hline CD105 & Qiagen ${ }^{\circledR}$ & QT00013335 \\
\hline CD73 & Qiagen ${ }^{\circledR}$ & QT00027279 \\
\hline$\beta$-Actin & $\begin{array}{l}\text { FORWARD: 5'-GGACTT CGA GCA AGA GAT GG-3' } \\
\text { REVERSE: 5'-AGC ACT GTG TTG GCG TAC AG-3' }\end{array}$ & \\
\hline
\end{tabular}

\section{8. siRNA Transfection}

siRNAs transfection in 10 samples of S-ASC and in 10 sample of V-ASC was performed using the INTERFERin TM transfection agent (Polyplus-Transfection, Illkirch, France), according to the manufacturer's instructions. Briefly, cells were seeded into six-well plates at a density of 250,000 cells/well or 96-well plates at a density of 3000 cells/well. The transfection agent and the siRNA complex were added to the cells and incubated for $72 \mathrm{~h}$ for expression analysis and $96 \mathrm{~h}$ for protein detection. The final concentration of SOX2 siRNA was $100 \mathrm{nM}$ for mRNA analysis, $150 \mathrm{nM}$ for protein detection and $40 \mathrm{nM}$ for NANOG siRNA. Each assay was performed in triplicate in at least three independent experiments. SOX2 was silenced using Stealth siRNA SOX2 HSS144045 (Invitrogen). siCONTROL Stealth siRNA Negative Control was used as a control (Invitrogen). NANOG was silenced by NANOG siRNA (Santa Cruz Biotechnology, Dallas, TX, USA), and control siRNAs were used as a no-target control (Santa Cruz Biotechnology). 


\subsection{Western Blot Analysis}

Proteins were extracted from adherent cultured cells isolated from 5 samples of S-ASC and 5 samples of V-ASC using RIPA buffer $(50 \mathrm{mM}$ Tris-HCl, pH 7.4, $150 \mathrm{mM} \mathrm{NaCl}, 1 \%$ Nonidet P40), supplemented with a protease inhibitor cocktail (Complete mini, Roche Diagnostics GmbH, Mannheim, Germany) and phosphatase inhibitors. Protein content was determined according to Bradford's method. Proteins were separated by Bio-Rad (Bio-Rad, Segrate, Italy), electrotransferred to nitrocellulose membrane and blotted with the following primary antibodies: rabbit antihuman SOX2 (Poly6308, BioLegend, San Diego, CA, USA), mouse antihuman Oct-4 (sc-5279, Santa Cruz Biotechnology), goat antihuman NANOG (sc-30331, Santa Cruz Biotechnology), mouse anti- $\beta$-actin IgG1 (A5441, Sigma-Aldrich) Secondary antibodies were goat anti-rabbit IgG-HRP (sc-2030, Santa Cruz Biotechnology), goat anti-mouse IgG-HRP (sc-2031, Santa Cruz Biotechnology) and donkey anti-goat IgG-HRP (sc-2033, Santa Cruz Biotechnology) (see Table 3). Antigen-antibody complexes were visualized using the ECL prime (Amersham, GE Healthcare Europe GmbH, Milan, Italy) on a CCD camera (Chemidoc, Bio-Rad, Milan, Italy). Western blot bands were quantified with ImageJ 1.48 software (National Institutes of Health, Bethesda, MD, USA).

Table 3. Antibodies used for characterization for stem cell markers.

\begin{tabular}{cccc}
\hline Primary Antibody/Localization Marker & Code Number & Dilution & Incubation \\
\hline NANOG, nuclear and cytoplasmatic & sc-30331, Santa Cruz Biotechnology & $1: 500$ & $\mathrm{o} / \mathrm{n}, 4^{\circ} \mathrm{C}$ \\
OCT3/4, nuclear & sc-5279, Santa Cruz Biotechnology & $1: 500$ & $\mathrm{o} / \mathrm{n}, 4^{\circ} \mathrm{C}$ \\
SOX2 nuclear & Poly6308, BioLegend & $1: 500$ & $\mathrm{o} / \mathrm{n}, 4{ }^{\circ} \mathrm{C}$ \\
\hline Secondary Antibody & Code Number & Diluition & Incubation \\
\hline Goat anti-rabbit IgG-HRP & sc-2030, Santa Cruz Biotechnology & $1: 2500$ & 90 min, r.t. \\
Goat anti-mouse IgG-HRP & sc-2031, Santa Cruz Biotechnology & $1: 2500$ & 90 min, r.t. \\
Donkey anti-goat IgG-HRP & sc-2033, Santa Cruz Biotechnology & $1: 2500$ & 90 min, r.t. \\
\hline
\end{tabular}

Santa Cruz Biotechnology, Dallas, Texas; BioLegend, San Diego, CA; o/n, overnight; r.t., room temperature.

\section{Conclusions}

The use of adipose-derived stem cell is promising in regenerative medicine and tissue engineering applications and constitutes a valuable resource in biotechnology. Our aim was to study the different expression of embryonic stem cell markers NANOG, SOX2 and OCT3/4 in ASCs derived from SAT and VAT tissue and to explore whether NANOG possesses a more prominent role in this network. Our experiments confirm the presence of the principal transcription factors that regulate pluripotency and plasticity in both S-ASC and V-ASC cells. In spheres, SOX2, OCT4 and NANOG genes were highly expressed when compared with adherent S-ASC and V-ASC cells. From our findings, NANOG seems to exert a hierarchical role in the network that regulates pluripotency, as its silencing causes downregulation of OCT3/4 and SOX2 genes in both S-ASCs and V-ASCs, while SOX2 silencing does not affect NANOG and OCT3/4 gene expression in both S-ASCs and V-ASCs. In the future, other methods will be necessary to further investigate whether NANOG downregulation in S-ASC and in V-ASC cells plays a role in the long-term differentiation of specialized cells. Finally, the lack of OCT4 silencing represents a limit for the definition of the single role of each network component. In conclusion, our results outline the importance of these data for future applications of ASC cells in regenerative medicine.

Supplementary Materials: Supplementary materials can be found at www.mdpi.com/1422-0067/18/6/1107/s1.

Acknowledgments: This work is dedicated to our former director Aldo Galluzzo, who prematurely died in 2011 when the Laboratory of Regenerative Medicine was created and research in this field started. The work was partially funded by PON 01_00829 2007/2013 with European Community funds administered by the Italian Ministry for the University and RIMEDRI PO FESR 2007/2013 (Carla Giordano, Scientific Director for both). 
Author Contributions: Maria Pitrone was responsible for the conception of the work and the design, collection and assembly of data, the data analysis and interpretation and manuscript writing. Giuseppe Pizzolanti was responsible for the collection and assembly of data and revision of the manuscript. Carla Giordano and Giuseppe Pizzolanti were responsible for the conception of the work and the design, provision of study material or patients and the revision of the manuscript. Maria Pitrone, Giuseppe Pizzolanti, Lorenzo Morini, Gianni Pantuso, Romina Ficarella and Sebastio Perrini contributed reagents/materials/analysis tools. Giuseppe Pizzolanti, Laura Tomasello, Antonina Coppola, Valentina Guarnotta, Romina Ficarella and Sebastio Perrini were responsible for data analysis and interpretation and drafting of the manuscript. Giuseppe Pizzolanti was responsible for the acquisition of data and revision of the manuscript. Carla Giordano and Francesco Giorgino were responsible for manuscript writing and revision of the manuscript. Carla Giordano was responsible for the conception of the work and the design, data analysis and interpretation, manuscript writing and final approval of the manuscript, the manuscript drafting, revising critically for important intellectual content and financial support. All authors agree to be accountable for all aspects of the work in ensure that questions related to the accuracy or integrity of any part of the work are appropriately investigated and resolved. All authors read and approved the final manuscript.

Conflicts of Interest: The authors declare no conflict of interest.

\section{Abbreviations}

$\begin{array}{ll}\text { S-ASC } & \text { Subcutaneous-adipose stem cell } \\ \text { V-ASC } & \text { Visceral-adipose stem cell } \\ \text { SVF } & \text { Stromal vascular fraction }\end{array}$

\section{References}

1. Gimble, J.M.; Katz, A.J.; Bunnell, B.A. Adipose-derived stem cells for regenerative medicine. Circ. Res. 2007, 100, 1249-1260. [CrossRef] [PubMed]

2. Bunnell, B.A.; Flaat, M.; Gagliardi, C.; Patel, B.; Ripoll, C. Adipose-derived stem cells: Isolation, expansion and differentiation. Methods 2008, 45, 115-120. [CrossRef] [PubMed]

3. Yu, G.; Floyd, Z.E.; Wu, X.; Halvorsen, Y.D.; Gimble, J.M. Isolation of human adipose-derived stem cells from lipoaspirates. Methods Mol. Biol. 2011, 702, 17-27. [CrossRef] [PubMed]

4. Zuk, P.A.; Zhu, M.; Mizuno, H.; Huang, J.; Futrell, J.W.; Katz, A.J.; Benhaim, P.; Lorenz, H.P.; Hedrick, M.H. Multilineage cells from human adipose tissue: Implications for cell-based therapies. Tissue Eng. 2001, 7, 211-228. [CrossRef] [PubMed]

5. Zuk, P.A.; Zuh, M.; Ashjian, P.; de Ugarte, D.A.; Huang, J.I.; Mizuno, H.; Alfonso, Z.C.; Fraser, J.K.; Benhaim, P.; Hedrick, M.H. Human adipose tissue is a source of multipotent stem cells. Mol. Biol. Cell 2002, 13, 4279-4295. [CrossRef] [PubMed]

6. Wang, S.; Qu, X.; Zhao, R.C. Clinical applications of mesenchymal stem cells. J. Hematol. Oncol. 2012, 30, 19. [CrossRef] [PubMed]

7. Wang, Z.; Oron, E.; Nelson, B.; Razis, S.; Ivanova, N. Distinct lineage specification roles for NANOG, OCT4, and SOX2 in human embryonic stem cells. Cell Stem Cell 2012, 10, 440-445. [CrossRef] [PubMed]

8. Boyer, L.A.; Lee, T.I.; Cole, M.F.; Johnstone, S.E.; Levine, S.S.; Zucker, J.P.; Guenther, M.G.; Kumar, R.M.; Murray, H.L.; Jenner, R.G.; et al. Core transcriptional regulatory circuitry in human embryonic stem cells. Cell 2005, 122, 947-956. [CrossRef] [PubMed]

9. Loh, Y.H.; Wu, Q.; Chew, J.L.; Vega, V.B.; Zhang, W.; Chen, X.; Bourque, G.; George, J.; Leong, B.; Liu, J.; et al. The OCT4 and NANOG transcription network regulates pluripotency in mouse embryonic stem cells. Nat. Genet. 2006, 38, 431-440. [CrossRef] [PubMed]

10. Tsai, C.C.; Su, P.F.; Huang, Y.F.; Yew, T.L.; Hung, S.C. Oct4 and Nanog directly regulate Dnmt1 to maintain self-renewal and undifferentiated state in mesenchymal stem cells. Mol. Cell 2012, 47, 169-182. [CrossRef] [PubMed]

11. Lengner, C.J.; Camargo, F.D.; Hochedlinger, K.; Welstead, G.G.; Zaidi, S.; Gokhale, S.; Scholer, H.R.; Tomilin, A.; Jaenisch, R. Oct4 expression is not required for mouse somatic stem cell self-renewal. Cell Stem Cell 2007, 1, 403-415. [CrossRef] [PubMed]

12. Liedtke, S.; Enczmann, J.; Waclawczyk, S.; Wernet, P.; Kögler, G. Oct4 and its pseudogenes confuse stem cell research. Cell Stem Cell 2007, 1, 364-366. [CrossRef] [PubMed] 
13. Pain, D.; Chirn, G.W.; Strassel, C.; Kemp, D.M. Multiple retropseudogenes from pluripotent cell-specific gene expression indicates a potential signature for novel gene identification. J. Biol. Chem. 2005, 280, 6265-6268. [CrossRef] [PubMed]

14. Hyslop, L.; Stojkovic, M.; Armstrong, L.; Walter, T.; Stojkovic, P.; Przyborski, S.; Herbert, M.; Murdoch, A.; Strachan, T.; Lakoa, M. Downregulation of NANOG Induces Differentiation of Human Embryonic Stem Cells to Extraembryonic Lineages. Stem Cells 2005, 8, 1035-1043. [CrossRef] [PubMed]

15. Korkola, J.E.; Houldsworth, J.; Chadalavada, R.S.; Olshen, A.B.; Dobrzynski, D.; Reuter, V.E.; Bosl, G.J.; Chaganti, R.S. Down-regulation of stem cell genes, including those in a 200-kb gene cluster at 12p13.31, is associated with in vivo differentiation of human male germ cell tumors. Cancer Res. 2006, 66, 820-827. [CrossRef] [PubMed]

16. Riccardi, C.; Nicoletti, I. Analysis of apoptosis by propidium iodide staining and flow cytometry. Nat. Protoc. 2006, 1, 1458-1461. [CrossRef] [PubMed]

17. Gronthos, S.; Franklin, D.M.; Leddy, H.A.; Robey, P.G.; Storms, R.W.; Gimble, J.M. Surface protein characterization of human adipose tissue-derived stromal cells. J. Cell. Physiol. 2001, 189, 54-63. [CrossRef] [PubMed]

18. Perrini, S.; Laviola, L.; Cignarelli, A.; Melchiorre, M.; de Stefano, F.; Caccioppoli, C.; Natalicchio, A.; Orlando, M.R.; Garruti, G.; de Fazio, M.; et al. Fat depot-related differences in gene expression, adiponectin secretion, and insulin action and signalling in human adipocytes differentiated in vitro from precursor stromal cells. Diabetologia 2008, 51, 155-164. [CrossRef] [PubMed]

19. Potdar, P.; Sutar, J. Establishment and molecular characterization of mesenchymal stem cell lines derived from human visceral \& subcutaneous adipose tissues. J. Stem Cells Regen. Med. 2010, 6, 26-35. [PubMed]

20. De Francesco, F.; Tirino, V.; Desiderio, V.; Ferraro, G.; D’Andrea, F.; Giuliano, M.; Libondi, G.; Pirozzi, G.; de Rosa, A.; Papaccio, G. Human CD34/CD90 ASCs are capable of growing as sphere clusters, producing high levels of VEGF and forming capillaries. PLoS ONE 2009, 4, e6537. [CrossRef] [PubMed]

21. Pittenger, M.F.; Mackay, A.M.; Beck, S.C.; Douglas, R.; Mosca, J.D.; Moorman, M.A.; Simonetti, D.W.; Craig, S.; Marshak, D.R. Multilineage potential of adult human mesenchymal stem cells. Science 1999, 284, 143-147. [CrossRef] [PubMed]

22. Barry, F.P.; Boynton, R.E.; Haynesworth, S.; Murphy, J.M.; Zaia, J. The monoclonal antibody SH-2, raised against human mesenchymal stem cells, recognizes an epitope on endoglin (CD105). Biochem. Biophys. Res. Commun. 1999, 265, 134-139. [CrossRef] [PubMed]

23. Sachs, P.C.; Francis, M.P.; Zhao, M.; Brumelle, J.; Rao, R.R.; Elmore, L.W.; Holt, S.E.; Patrick, C.S.; Francis, M.P.; Zhao, M.; et al. Defining essential stem cell characteristics in adipose-derived stromal cells extracted from distinct anatomical sites. Cell Tissue Res. 2012, 349, 505-515. [CrossRef] [PubMed]

24. Chambers, I.; Colby, D.; Robertson, M.; Nichols, J.; Lee, S.; Tweedie, S.; Smith, A. Functional expression cloning of Nanog, a pluripotency sustaining factor in embryonic stem cells. Cell 2003, 30, 643-655. [CrossRef]

25. Ng, H.H.; Surani, M.A. The transcriptional and signalling networks of pluripotency. Nat. Cell Biol. 2011, 13, 490-496. [CrossRef] [PubMed]

26. Kuroda, T.; Tada, M.; Kubota, H.; Kimura, H.; Hatano, S.Y.; Suemori, H.; Nakatsuji, N.; Tada, T. Octamer and Sox elements are required for transcriptional cis regulation of NANOG gene expression. Mol. Cell. Biol. 2005, 25, 2475-2485. [CrossRef] [PubMed]

27. Park, I.H.; Zhao, R.; West, J.A.; Yabuuchi, A.; Huo, H.; Ince, T.A.; Lerou, P.H.; Lensch, M.W.; Daley, G.Q. Reprogramming of human somatic cells to pluripotency with defined factors. Nature 2008, 451, 141-146. [CrossRef] [PubMed]

28. Freberg, C.T.; Dahl, J.A.; Timoskainen, S.; Collas, P. Epigenetic reprogramming of OCT4 and NANOG regulatory regions by embryonal carcinoma cell extract. Mol. Biol. Cell 2007, 18, 1543-1553. [CrossRef] [PubMed]

29. Goodell, M.A. Stem-cell "plasticity": Befuddled by the muddle. Curr. Opin. Hematol. 2003, 10, $208-213$. [CrossRef] [PubMed]

30. Mi tsui, K.; Tokuzawa, Y.; Itoh, H.; Segawa, K.; Murakami, M.; Takahashi, K.; Maruyama, M.; Maeda, M.; Yamanaka, S. The homeoprotein Nanog is required for maintenance of pluripotency in mouse epiblast and ES cells. Cell 2003, 113, 631-664. [CrossRef]

31. Okita, K.; Ichisaka, T.; Yamanaka, S. Generation of germline-competent induced pluripotent stem cells. Nature 2007, 19, 313-317. [CrossRef] [PubMed] 
32. Chew, J.L.; Loh, Y.H.; Zhang, W.; Chen, X.; Tam, W.L.; Yeap, L.S.; Li, P.; Ang, Y.S.; Lim, B.; Robson, P.; et al. Reciprocal transcriptional regulation of Pou5f1 and SOX2 via the OCT4/SOX2 complex in embryonic stem cells. Mol. Cell. Biol. 2005, 25, 6031-6046. [CrossRef] [PubMed]

33. Sanges, D.; Cosma, M.P. Reprogramming cell fate to pluripotency: The decision-making signalling pathways. Int. J. Dev. Biol. 2010, 54, 1575-1587. [CrossRef] [PubMed]

34. Kim, J.H.; Jee, M.K.; Lee, S.Y.; Han, T.H.; Kim, B.S.; Kang, K.S.; Kang, S.K. Regulation of adipose tissue stromal cells behaviors by endogenic OCT4 expression control. PLoS ONE 2009, 4, e7166. [CrossRef] [PubMed]

35. Suzuki, A.; Raya, A.; Kawakami, Y.; Morita, M.; Matsui, T.; Nakashima, K.; Gage, F.H.; Rodriguez-Esteban, C.; Izpisua Belmonte, J.C. Nanog binds to Smad1 and blocks bone morphogenetic protein-induced differentiation of embryonic stem cells. Proc. Natl. Acad. Sci. USA 2006, 103, 10294-10299. [CrossRef] [PubMed]

36. Vallier, L.; Mendjan, S.; Brown, S.; Chng, Z.; Teo, A.; Smithers, L.E.; Trotter, M.W.; Cho, C.H.; Martinez, A.; Rugg-Gunn, P.; et al. Activin/Nodal signaling maintains pluripotency by controlling NANOG expression. Development 2009, 136, 1339-1349. [CrossRef] [PubMed]

37. Wang, J.; Rao, S.; Chu, J.; Shen, X.; Levasseur, D.N.; Theunissen, T.W.; Orkin, S.H. A protein interaction network for pluripotency of embryonic stem cells. Nature 2006, 444, 364-368. [CrossRef] [PubMed]

38. Goke, J.; Jung, M.; Behrens, S.; Chavez, L.; O'Keeffe, S.; Timmermann, B.; Lehrach, H.; Adjaye, J.; Vingron, M. Combinatorial binding in human and mouse embryonic stem cells identifies conserved enhancers active in early embryonic development. PLoS Comput. Biol. 2011, 7, e1002304. [CrossRef] [PubMed]

39. Fujikura, J.; Yamato, E.; Yonemura, S.; Hosoda, K.; Masui, S.; Nakao, K.; Miyazaki, J.; Niwa, H. Differentiation of embryonic stem cells is induced by GATA factors. Genes Dev. 2002, 16, 784-789. [CrossRef] [PubMed]

40. Koutsourakis, M.; Langeveld, A.; Patient, R.; Beddington, R.; Grosveld, F. The transcription factor GATA6 is essential for early extraembryonic development. Development 1999, 126, 723-732. [PubMed]

41. Morrisey, E.E.; Tang, Z.; Sigrist, K.; Lu, M.M.; Jiang, F.; Ip, H.S.; Parmacek, M.S. GATA6 regulates HNF4 and is required for differentiation of visceral endoderm in the mouse embryo. Genes Dev. 1998, 12, 3579-3590. [CrossRef] [PubMed]

42. Kunath, T.; Strumpf, D.; Rossant, J. Early trophoblast determination and stem cell maintenance in the mouse-A review. Placenta 2004, 25, S32-S38. [CrossRef] [PubMed]

43. Masui, S.; Nakatake, Y.; Toyooka, Y.; Shimosato, D.; Yagi, R.; Takahashi, K.; Okochi, H.; Okuda, A.; Matoba, R.; Sharov, A.A.; et al. Pluripotency governed by SOX2 via regulation of Oct3/4 expression in mouse embryonic stem cells. Nat. Cell Biol. 2007, 9, 625-635. [CrossRef] [PubMed] 